\title{
JUAL BELI HEWAN TONAK LOPEH KAJIAN HUKUM ISLAM: Studi di Desa Gema Kampar-Kiri Hulu
}

\author{
Iffaty Nasyiah dan Idkham Khalid \\ UIN Maulana Malik Ibrahim Malang \\ Email: iffaty.nasyiah@gmail.com
}

\begin{abstract}
The background of this study is the habit of Gema Kampar Kiri villagers at Hulu district in terms of buying and selling cattle. They call it,"tonak lopeh" transaction. Its practice is different from the common transaction practice i.e the purchased livestock does not directly switch to the buyer and it is purchased only partially, ranging from one sixteenth to a half. Another uniqueness is that these cattle are not kept in the cage, but are released in the meadow. Based on this background, the researchers formulate a problem that is how the view of Islamic law about the practice of this transaction. This research is an empirical law research with sociological juridical approach. The result of this research is the sale of "partial" livestock in the opinion of Imam Nawawi in his book Minhaj al Thalibin is in accordance with Islamic law because the object of sale and purchase should not be in part, unless the value and benefit from the goods is not reduced.
\end{abstract}

Penelitian ini dilatarbelakangi oleh adanya kebiasaan atau adat masyarakat Desa Gema Kecamatan Kampar Kiri Hulu kabupaten Kampar Propinsi Riau dalam hal jual beli hewan tonak lopeh. Mereka menyebutnya dengan jual beli "tonak lopeh". Praktik jual beli "tonak lopeh" ini mempunyai perbedaan dengan jual beli pada umumnya yaitu hewan ternak yang sudah dibeli tidak langsung beralih kepada si pembeli dan dibeli hanya sebagian mulai seperenambelas sampai setengah bagiannya saja. Keunikan lainnya yaitu hewan ternak ini bukan hewan yang dipelihara di dalam kandang melainkan dilepaskan di padang rumput. Dari latar belakang tersebut, peneliti merumuskan satu permasalahan yaitu bagaimana pandangan hukum Islam mengenai praktik jual beli tersebut. 
Pembahasan hukum Islam di sini terbatas pada jual beli menurut Imam Nawawi dan urf. Penelitian ini merupakan penelitian hukum empiris dengan pendekatan yuridis sosiologis. Hasil yang didapat menunjukkan bahwa jual beli hewan tonak lopeh "sebagian" menurut pendapat Imam Nawawi dalam kitabnya Minhaj al Thalibin sudah sesuai dengan hukum Islam karena objek jual belinya meskipun hanya sebagian tidak mengurangi nilai dan manfaat dari barang tersebut. Sedangkan dalam kajian urf, praktik demikian termasuk ke dalam urf mashlahah karena memberikan manfaat bagi masyarakat.

Keywords: buying and selling, Islamic law, urf

\section{Pendahuluan}

Manusia disebut dengan makhluk sosial, makhluk yang tidak dapat hidup sendiri dan selalu membutuhkan yang lain dalam memenuhi segala kebutuhan hidupnya. Hal tersebut disarikan dari dua hubungan manusia, yaitu hubungan manusia dengan Tuhannya (ibadah) dan hubungan manusia dengan sesamanya (muamalah) (Mahfudh, 2014: xxxii).

Sebagai makhluk sosial, manusia tidak bisa lepas untuk berhubungan dengan orang lain dalam kerangka memenuhi kebutuhan hidupnya. Kebutuhan manusia sangat beragam, sehingga seringkali secara pribadi ia tidak mampu untuk memenuhinya dan harus berhubungan dengan orang lain. Hubungan antara satu manusia dengan manusia lain dalam memenuhi kebutuhan harus berdasarkan aturan yang ada, termasuk salah satunya hubungan jual beli yang mempunyai asas konsensualisme. Asas ini mengandung makna bahwa dalam jual beli harus ada kesepakatan antara kedua belah pihak. Hubungan ini merupakah fitrah yang sudah ditakdirkan oleh Allah SWT, karena ia merupakan kebutuhan sosial sejak manusia mulai mengenal arti hak dan kewajiban. Islam sebagai agama yang komperhensif dan universal memberikan aturan yang cukup jelas dalam akad atau kontrak untuk dapat diimplementasikan dalam setiap masa.

Jual beli merupakan salah satu bentuk muamalah, yaitu perwujudan maslahah yang disyariatkan Islam. Jual beli sudah ada sejak dulu, meskipun bentuknya berbeda. Jual beli juga dibenarkan dan berlaku sejak zaman rasulullah Muhammad SAW sampai sekarang. Jual beli mengalami perkembangan seiring pemikiran dan pemenuhan kebutuhan masyarakat. Dalam proses transaksi jual beli tonak lopeh (liar), paling tidak melibatkan dua pihak yaitu penjual dan pembeli, keduanya harus memenuhi rukun dan syarat sesuai hukum jual beli dalam syariat Islam. Allah SWT telah menghalalkan praktik jual beli sesuai ketentuan dan syariatNya. Dalam surah al Baqarah: 275 Allah SWT 
berfirman: "...dan Allah telah menghalalkan jual beli dan mengharamkan riba..." (QS. al Baqarah: 275).

Jual beli dinyatakan sah apabila memenuhi rukun dan syarat jual beli. Rukun jual beli berarti sesuatu yang harus dipenuhi dalam jual beli. Apabila salah satu rukun jual beli tidak terpenuhi, maka jual beli tidak sah menurut aturan syariat.

Desa Gema terletak di kecamatan Kampar Kiri Hulu kabupaten Kampar propinsi Riau. Desa Gema adalah desa yang dikelilingi perbukitan dan di antaranya mengalir sungai yang jernih. Beberapa area di pinggiran desa ini terdapat padang rumput yang cukup luas dan subur. Mayoritas penduduk desa ini berprofesi sebagai petani, biasanya warga Gema memiliki kebun yang ditanami jagung, singkong, dan sawit. Di samping bertani, mereka juga memiliki hewan ternak seperti sapi, kerbau, kambing dan lainnya.

Pada umumnya hewan ternak dirawat atau digembalakan dalam kandang dan diberi makan dan minum oleh pemiliknya. Namun lain halnya dengan hewan tonak lopeh yang berlaku di Desa Gema ini. Tonak lopeh merupakan menernak atau menggembalakan hewan ternak dengan cara melepaskannya di sekitar pedesaan tanpa seutas tali atau dengan kata lain tidak di dalam kandang, dan dibiarkan secara lepas mencari makan di sekitar desa. Karena hewan ternak mereka diternak lepas, maka warga yang memiliki kebun seperti jagung, singkong dan lain-lain harus memasang pagar yang bisa mencegah ternak masuk kebun dan merusak tanaman. Ternak tersebut biasa hidup dan mencari makan secara bergerombol atau berkelompok dan mendiami padang rumput di pinggiran desa dan sesekali mengitari perkampungan warga. Ada beberapa padang rumput yang menjadi tempat hidup tonak lopeh warga Desa Gema ini, dan setiap padang rumput ada seorang penjaga yang dipercaya warga desa atau yang biasa melihat dan menjaga ternak mereka yang disebut dengan "Ketua Padang".

Jual beli hewan tonak lopeh merupakan suatu kegiatan yang sudah dikenal oleh masyarakat pada umumnya. Setelah jual beli dilakukan dan terjadi kesepakatan, hewan ternak tersebut menjadi milik pembeli sedangkan uang yang dibayarkan pembeli menjadi milik penjual. Namun lain halnya yang terjadi di desa Gema ini. Selain transaksi jual beli ternak sebagaimana di atas, terdapat jual beli ternak "separuh" (setengah bagian), "seperempat" (seperempat bagian), "seperdelapan”, dan "seperenambelas" dari satu ekor hewan ternak yang diperjualbelikan. Dalam transaksinya, biasanya ada penjual hewan ternak yang menawarkan kepada warga untuk membeli kerbaunya 
separuh (setengah bagian) maupun sebaliknya, pembeli menanyakan kepada pemilik kerbau, apakah bisa pemilik kerbau menjualnya separuh (setengah bagian). Kemudian penjual menaksir harga sesuai umur, dan dengan harga yang berlaku di desa, atau bertanya kepada warga yang biasa menjadi penjual ternak ke rumah potong hewan. Ketika harga sudah diketahui, karena kesepakatan jual beli separuh (setengah bagian), kemudian pembeli membayar setengah dari harga taksiran. Kerbau tersebut tetap digembalakan oleh si penjual. Dalam penelitian ini, peneliti hanya akan membahas mengenai praktek jual beli tonak lopeh menurut hukum Islam, khususnya dalam kajian jual beli menurut Imam Nawawi dalam kitabnya Minhaj al Thalibin dan urf.

Sebagaimana kita ketahui, jual beli itu dianggap sah menurut hukum Islam atau syariat Islam karena memenuhi syarat dan rukun jual beli. Apabila suatu transaksi jual beli tersebut tidak memenuhi salah satu rukun atau syarat jual beli, maka jual beli tersebut dihukumi cacat. Setelah terjadi transaksi jual beli, barang yang diperjualbelikan dimiliki sepenuhnya oleh pembeli. Namun fakta yang terjadi di desa Gema bahwa hewan ternak yang diperjualbelikan tidak dimiliki sepenuhnya oleh pembeli melainkan sebagiannya.

\section{Metode Penelitian}

Jenis penelitian ini adalah penelitian hukum empiris, yaitu penelitian dengan mengambil data-data dari lapangan sebagai sumber data utama, seperti hasil wawancara dan observasi. Penelitian hukum empiris digunakan untuk menganalisis hukum yang dilihat sebagai perilaku masyarakat yang berpola dalam kehidupan masyarakat yang selalu berinteraksi dan berhubungan dalam aspek kemasyarakatan (Sunggono, 2003: 43).

Pendekatan penelitian adalah metode atau cara mengadakan penelitian. Pendekatan penelitian disesuaikan dengan jenis penelitian. Pendekatan pada penelitian ini adalah yuridis-sosiologis, artinya suatu penelitian yang dilakukan terhadap keadaan nyata masyarakat atau lingkungan masyarakat dengan maksud dan tujuan untuk menemukan fakta (fact-finding), yang kemudian menuju pada identifikasi (problem-identification) dan pada akhirnya menuju kepada penyelesaian masalah (problem-solution).

Lokasi yang digunakan untuk pengambilan data dalam penelitian ini adalah di desa Gema kecamatan Kampar Kiri Hulu, kabupaten Kampar, provinsi Riau.

Sumber data yang digunakan ialah sumber data primer dan sekunder, data primer merupakan data yang berasal dari lapangan. Data lapangan 
itu diperoleh dari responden yaitu orang atau kelompok masyarakat yang memberikan jawaban atas pertanyaan yang diajukan peneliti dan memberikan keterangan yang dibutuhkan. Responden dipilih secara purposif yaitu orang atau masyarakat yang pernah terkait secara langsung dengan praktik jual beli hewan tonak lopeh. Sumber data sekunder adalah sumber data yang tidak langsung memberikan data kepada penulis melainkan dari pihak lain, tidak langsung diperoleh peneliti dan subjek penelitiannya (Azwar, 2013: 91). Sumber data sekunder disini berupa buku-buku literatur, jurnal, karya-karya ilmiah atau hasil-hasil penelitian yang berkaitan dengan masalah yang akan diteliti.

\section{Pembahasan}

Bapak Ahmad Nasri sebagai salah satu narasumber, pernah menjual hewan tonak lopeh di Desa Gema Kecamatan Kampar Kiri Hulu. Berikut penuturan beliau ketika ditanya tentang apa yang dimaksud dengan jual beli hewan tonak lopeh di Desa Gema Kecamatan Kampar Kiri Hulu:

"tonak lopeh tu yo punyo kobau awak, punyo jawi awak balopen di padang kobau. jadi mamoli kobau atau jawi tu ado yang sapagho adonan sakaki, ado nan saparlapan, ado juo nan sapar onambole, juo boli tonak ko la ado sajak ninik moyangughang awak ko young. Biasonyo dansanak ughang siko nan tingge di kota ughang siko, ughang desa subolah ado juo nan mboli kobau jo jawi ado".

Dari wawancara tersebut dapat dipahami bahwa ternak lepas atau tonak lopeh adalah hewan yang dilepaskan di suatu tempat (yang mereka namakan padang kerbau) atau lahan warga yang kosong yang tidak dijadikan kebun. Sedangkan jual beli ternak lepas adalah jual beli hewan ternak yang dilepaskan di padang kerbau dimaksud. Dalam prosesnya, ada warga yang membeli hanya sebagian saja dari hewan ternak tersebut mulai dari separuh, seperempat, seperdelapan, sampai seperenambelas bagian saja. Jual beli seperti ini sudah berlangsung dalam kurun yang lama secara turun-temurun. Hampir semua warga pernah melakukan jual beli hewan ternak lepas ini. Dari penjelasan bapak Nasri tersebut dapat diketahui bahwa jual beli hewan tonak lopeh merupakan suatu transaksi yang sering dilakukan masyarakat desa Gema dan beberapa desa sekitarnya. Jual beli ini dilakukan dengan cara penjual menawarkan kepada pembeli hewan ternaknya atau pembeli datang dan menemui pemilik hewan ternak tersebut. Kemudian penjual dan pembeli menuju padang rumput untuk melihat secara langsung hewan yang hendak diperjualbelikan. Setelah itu diadakanlah ijab qabul (serah terima). Dengan kata lain mereka telah melakukan suatu perjanjian dan menemukan kesepakatan atau konsensus jual 
beli. Perjanjian ini dalam hukum Islam disebut dengan akad, sedangkan akad jual beli dinamakan murabahah. Dengan demikian murabahah adalah akad jual beli antara dua belah pihak, dimana pembeli dan penjual menyepakati harga jual yang terdiri atas harga beli ditambah ongkos pembelian dan keuntungan bagi penjual. Pemahaman lain murabahah adalah akad jual beli barang dengan menyatakan harga perolehan dan keuntungan (margin) dan disepakati oleh penjual dan pembeli. Murabahah dapat dilakukan secara tunai, bisa bayar tangguh atau bayar dengan angsuran (Setiady, 2014: 520).

Akad umumnya diartikan sebagai penawaran dan penerimaan yang berakibat pada konsekuensi hukum tertentu. Akad berarti kesepakatan yang bersandar pada penawaran dan penerimaan (ijab qabul) antara para pihak yang terlibat dalam akad dengan prinsip hukum dalam suatu urusan (objek) (Jahar, dkk., 2013: 259).

Proses melakukan akad jual beli hewan tonak lopeh menurut bapak Khatmi Amril (warga yang pernah menjual hewan tonak lopeh) adalah sebagai berikut:

"cagho nak mamboli atau manjuo kobau jo jawi tu biasonyo ughang nak manjuo menawarkan ka pamboli soalnyo butuh piti copek. Siap tu kaduonyo ka padang kobau manengok kobau kan diboli. Dan disitu sakali ditaksir ogo kobau tu berapo, ijab kobulnya ditompek ado juo yang ijab qabulnyo di umah ndak parolu manengok langsung kobau tu di padang do condo iko ijab qabulnyo :"pembeli :den bolikobau sianu ko jo ogo sekian.", kemudian penjual: "iyo lah den temo pit. i". Biasonyo ughang sadan sanak jadi atas dasar picayo ajo juo boli bisa dilakukan, biasanaya ado ketua padang nan menengok kobau jo jawi di sabuah padang dan inyo tontu sodo kobau jo yang punyo sakali".

Bapak Khatmi Amri menjelaskan proses jual beli hewan tonak lopeh ini dengan lebih rinci, biasanya si penjual menawarkan kepada pembeli hewan ternak yang dipunyainya kepada warga lain yang ingin membeli hewan ternak. Setelah ditemukan calon pembeli, mereka kemudian menuju padang kerbau untuk melihat langsung kerbau atau sapi yang akan diperjualbelikan. Biasanya ijab qabul disepakati di tempat. Namun ada juga yang melakukan ijab qabul di rumah saja, dan ini didasari atas dasar percaya karena memiliki hubungan keluarga. Biasanya ketua padang yang bertugas dan dipercaya mengawasi hewan ternak warga, bahkan dia mengetahui siapa pemilik masing-masing ternak tersebut.

Dari penjelasan tersebut dapat ditangkap terjadinya prosedur akad jual beli pada umumnya yaitu adanya penawaran dan penerimaan atau ijab qabul. ObJek yang diperjanjikan juga ada dan jelas, kecuali jika ada hubungan 
keluarga di antara mereka, maka objek jual beli terkadang tidak diperlihatkan karena menggunakan dasar kepercayaan.

Akad juga diartikan sebagai ikatan atau hubungan di antara ijab qabul yang memiliki akibat hukum terhadap hal-hal yang diakadkan. Pengertian akad mendasarkan pada kesepakatan atau kerelaan bersama. Akad dan perjanjian diartikan sama, yaitu tercapainya ijab yang dinyatakan oleh salah satu pihak dan dilakukannya qabul dari pihak lain secara sah menurut syara'. Pengertian ini menandakan bahwa dalam ijab qabul terjadi kesepakatan bersama, baik lisan, isyarat, maupun tulisan antara dua pihak atau lebih yang mengikat semua pihak yang terlibat untuk melaksanakan apa yang telah menjadi kesepakatan (Jahar, dkk., 2013: 259).

Ada akad yang namanya jual beli separuh (setengah bagian) atau dua pemilik, sakaki (satu perempat), saparlapan (satu perdelapan), dan sapar onambole (satu per enambelas bagian). Bapak Khairil Anwar, yang pernah membeli hewan tonak lopeh, menuturkan:

"kalau nak mamboli kobau bisa tanyo ka ketua padang, kobau siapo nan bisa diboli. baik boli sakaki atau siku kobau langsuong. Mamboli kobau tu yo langsung ka umah uwang nan mamunyo kobau tu. Kalo ogo kobau tu biaso ikuik ogo ka nan panjuo kobau ka uma potong. Jadi biaso minta ka sianu tu yang naksir ogonyo".

Proses jual beli hewan bisa diawali dengan seorang yang ingin mencari atau membeli hewan ternak lepas. Bapak Khairil Anwar mengatakan, jika demikian, biasanya pembeli bertanya langsung kepada ketua padang, hewan siapa yang bisa dibeli. Setelah mengetahui pemilik dari hewan ternak lepas tersebut dari ketua padang, pembeli mendatangi rumah pemilik kerbau itu. Untuk harganya, bisa ditanyakan kepada yang ahli atau sudah biasa melakukan jual beli ternak, dalam arti ada taksiran harga yang dapat dilakukan oleh warga baik warga desa sendiri atau dari warga desa tetangga. Dengan taksiran harga tersebut calon pembeli dapat memperkirakan harga hewan yang akan dibeli.

\section{Jual Beli Hewan Tonak lopeh menurut Imam Nawawi Dalam Minhaj al Thalibin}

Hukum dan sifat jual beli dibagi menjadi dua macam, yakni jual beli yang dikatakan sah (shahih) dan jual beli yang dinyatakan tidak sah (batal atau fasid). Jual beli dikatakan sah apabila memenuhi ketentuan syara', baik rukun maupun syarat-syaratnya, sedangkan jual beli yang tidak sah adalah jual beli yang tidak memenuhi salah satu rukun dan syarat sehingga jual beli menjadi 
rusak (fasid) atau batal (Syafi' i, 2001: 91-92).

Jual beli dapat dikatakan sah jika telah memenuhi rukun dan syaratnya. Adapun rukun jual beli yang disyaratkan dalam madzhab Syafi'i adalah sebagai berikut: 1) Adanya Aqid (orang yang berakad) dalam hal ini adalah adanya penjual dan pembeli; 2) Adanya Ma'qud alaih (barang yang diperjualbelikan); 3) Adanya Sighat (ijab dan qabul) (Nawawi, 2005: 210-211).

Jual beli hewan tonak lopeh telah memenuhi rukun-rukun tersebut. Pertama, adanya Aqid, yakni yang menjadi pihak yang bertransaksi, yaitu warga desa Gema kecamatan Kampar Kiri Hulu sebagai pihak pembeli dan pihak penjual, dalam hal ini pembeli bisa lebih dari satu orang. Kedua, adanya Ma'qud Alaih, yaitu obyek yang diperjualbelikan. Objek yang diperjualbelikan adalah binatang ternak yang dilepas secara bebas seperti sapi dan kerbau. Ketiga, adanya Sighat. Ijab yang diucapkan oleh pembeli yang secara jelas mengatakan bahwa dia ingin membeli objek jual beli tersebut kemudian qabulnya diucapkan oleh penjual. Proses ijab qabul ini juga dilalui dalam jual beli hewan tonak lopeh. Sebagaimana dikatakan oleh bapak Khatmi Nasri :

"cara menjual atau membeli kerbau dan sapi itu biasanya si penjual menawarkan kepada pembeli, dikarenakan butuh uang dalam waktu yang mendesak. Setelah itu keduanya (penjual dan pembeli) melihat langsung kerbau atau sapi yang akan diperjualbelikan. Biasanya ijab qabul disepakati di tempat. Namun ada juga yang melakukan ijab qabul di rumah saja, dan ini didasari atas dasar percaya karena memiliki hubungan keluarga, biasanya ada yang namanya ketua padang yang bertugas dan dipercaya mengawasi hewan ternak warga, bahkan dia mengetahui siapa pemilik masing-masing ternak tersebut".

Adapun syarat jual beli adalah sebagai berikut:

1. Syarat dalam ijab dan qabul. Ijab seperti bi'tuka dan malaktuka dan qabul seperti isytaraytu dan tamalaktu. Dalam hal ijab dan qabul, maka diperbolehkan untuk mendahulukan perkataan pembeli artinya tidak harus ijab dan qabul itu perkataan penjual yang didahulukan. Selain itu dalam ijab qabul, pembeli dan penjual bisa menggunakan katakata kinayah atau bahasa kiasan dalam menyampaikan maksud jual beli suatu barang menurut pendapat yang lebih shahih. Disyaratkan pula dalam mengucapkan ijab dan qabul tidak diperbolehkan adanya pemisah yang lama di antara kedua lafadz tersebut (ijab dan qabul). Selain itu antara ucapan penjual dan pembeli harus selaras, artinya ijab dan qabul harus sinkron seperti perkataan pembeli: "saya beli dari kamu kertas ini seharga 1000 rupiah”, kemudian penjual 
mengucapkan qabul: "saya terima dengan harga 1000 rupiah" dan tidak boleh sebaliknya;

2. Syarat Aqid. Aqid disyaratkan bagi orang yang bertransaksi, ia harus pintar (rusyd);

3. Syarat Mabi' atau Ma'qud Alaih. Mabi' atau Ma'qud Alaih harus memenuhi lima syarat, yaitu: suci, bermanfaat, dimungkinkan dapat diserahkan, dimiliki penuh oleh penjual dan diketahui secara jelas (Nawawi, 2005: 211).

Dalam prosesnya, biasanya jual beli hewan tonak lopeh menggunakan sighat atau ucapan tidak terstruktur atau pasti seperti: "den boli kobau sianu sapagho kobau dengan ogo sakian". "saya beli kerbau anda separuh bagian saja dengan harga sekian”. Kemudian si penjual mengucapkan kalimat qabul seperti: "oh iyo la den temo". "oh ya sudah saya terima". Meskipun sighat jual beli yang terjadi tidak terstruktur, akan tetapi antara ijab dan qabul tersebut sinkron dan sesuai. Sehingga sesuai dengan apa yang disebutkan Imam Nawawi di atas yakni harus ada kesesuaian antara ijab dan qabul.

Tidak seperti kebanyakan jual beli hewan ternak yang berlaku saat ini, yang dalam setiap jual beli hewan objeknya seekor, jual beli hewan tonak lopeh tidak perlu membeli seekor. Pihak pembeli dapat membeli setengah, seperempat, seperdelapan atau seperenambelas bagian saja. Begitu pula penawaran oleh pihak penjual. Kedua belah pihak sama-sama tahu dan rela untuk melakukan transaksi jual beli tersebut tanpa adanya paksaan.

Salah satu dasar mutlak untuk sahnya akad perjanjian adalah suka sama suka atau saling rela, oleh karena itu rusaknya kualifikasi ini akan menyebabkan batalnya suatu akad. Para ulama fikih juga sudah membahas secara detail tentang sebab-sebab yang dapat merusak keadaan rela sama rela (an taradlin). Dalam al Quran surat an Nisa': 29 Allah SWT berfirman yang artinya:

"Hai orang-orang yang beriman, janganlah kamu saling memakan harta sesamamu dengan jalan yang bathil, kecuali dengan jalan perniagaan yang berlaku dengan suka sama suka di antara kamu. Dan janganlah kamu membunuh dirimu, Sesungguhnya Allah adalah Maha Penyayang kepadamu." (Depag, 2005) (Ardhinata, 2015: 52).

Sedangkan syarat kedua yang berkaitan dengan aqid atau orang yang bertransaksi seperti yang disebutkan di atas adalah ia harus pintar (rasyd) dan selain itu bagi para pihak tersebut tidak dipaksa dalam melakukan transaksi jual beli tersebut oleh orang lain (Nawawi, 2005: 210). Apabila kita lihat dalam praktek yang terjadi di desa Gema kecamatan Kampar Kiri Hulu, para pihak yang bertransaksi adalah warga desa Gema kecamatan Kampar Kiri Hulu yang 
sudah berkeluarga, dengan kisaran usia 18 tahun ke atas. Dilihat dari umur para pihak yang bertransaksi maka peneliti menyimpulkan bahwa mereka adalah orang yang sudah memiliki kepintaran dalam membedakan antara yang baik dan buruk atau benar dan salah, selain itu dalam melakukan transaksi mereka melakukanya dengan sukarela atau tidak ada unsur paksaan, sehingga syarat yang kedua yang berhubungan dengan para pihak yang bertransaksi di desa Gema kecamatan Kampar Kiri Hulu sesuai dengan syarat yang ditetapkan oleh Imam Nawawi.

Syarat selanjutnya adalah syarat yang berkaitan dengan mabi' (obyek jual beli) yakni: harus suci, bermanfaat, dimungkinkan dapat diserahkan, dimiliki penuh oleh penjual dan diketahui secara jelas (Nawawi, 2005: 211). Jika dikaitkan dengan praktek jual beli yang terjadi di Desa Gema kecamatan Kampar Kiri Hulu, maka dapat diuraikan sebagai berikut : pertama, obyek jual beli yang terjadi di desa Gema kecamatan Kampar Kiri Hulu adalah berupa sapi dan kerbau, dan objek tersebut termasuk dalam kategori hewan yang suci tidak seperti anjing dan babi, maka dari itu syarat pertama dari mabi' telah terpenuhi. Kedua, harus mempunyai manfaat. Kerbau dan sapi termasuk dalam kategori bermanfaat karena kerbau atau sapi dapat dimanfaatkan untuk membajak sawah, dikembangbiakkan, juga untuk dikonsumsi oleh manusia. Ketiga, dapat diserahkan. Meskipun hewan tonak lopeh tidak secara langsung berada di tangan pembeli, namun terdapat keyakinan secara turun-temurun bahwa pada saatnya nanti akan terdapat penyerahan secara nyata baik berupa hasil penjualan hewan tersebut maupun berupa daging yang sudah siap untuk dikonsumsi. Dikatakan tidak sah apabila barang yang dijualbelikan adalah seperti barang yang dighasab, begitu juga tidak sah menjual sebagian tertentu dari suatu barang seperti wadah dan pedang atau yang semisalnya (Nawawi, 2005: 211). Barang yang diperjualbelikan tidak boleh separuhnya kecuali tidak berkurang nilai dan manfaat dari barang tersebut. (Nawawi, 2005: 211). Obyek jual beli hewan ternak ini meskipun dibeli sebagiannya saja, tidak mengurangi nilai atau manfaatnya. Tidak seperti pembelian sebagian wadah atau pedang (sebagaimana dimisalkan oleh Imam Nawawi) atau pembelian sapu tetapi gagangnya saja, pembelian setrika tetapi hanya kabelnya saja.

Keempat, objek jual beli. Obyek jual beli harus dimiliki sepenuhnya oleh si penjual kecuali menjualkan barang milik orang lain dengan izin si pemilik barang tersebut. Adapun jual beli sapi atau kerbau yang terjadi di desa Gema Kecamatan Kampar Kiri Hulu, objek jual beli adalah benar-benar milik si penjual meskipun sapi atau kerbau tersebut dilepas di padang rumput, 
hal itu dikuatkan oleh ketua padang (yaitu orang yang bertugas mengawasi hewan ternak di suatu padang ternak dimana ia mengetahui keseluruhan hewan yang menjadi tanggungjawabnya). Kelima, barang yang diperjualbelikan dapat diketahui secara dzat, sifat dan ukuranya, maka apabila mabi' atau obyek jual belinya tidak diketahui baik secara dzat, sifat dan ukuranya, maka menjadi tidak sah (Nawawi, 2005: 211-212). Dalam praktek jual beli hewan tonak lopeh, penjual dan pembeli masing-masing mengetahui dzat dari barang yang diperjualbelikan yakni berupa sapi atau kerbau Akan tetapi di sisi lain, penjual dan pembeli kadangkala tidak mengetahui secara pasti sifat dan ukuran objek jual beli tersebut karena pembeli hanya menyampaikan bahwa ia hanya membeli separuh dari sapi atau kerbau yang diperjualbelikan tersebut dan pembeli juga tidak menentukan bagian pasti yang dibeli. Dengan kata lain terjadi gharar, tetapi karena kebiasaan atau adat ini berlaku turun-menurun sebagaimana dijelaskan responden, maka dapat dimengerti bahwa dengan harga yang ditawarkan penjual, pembeli pasti dapat memperkirakan ukuran sapi atau kerbau yang akan diperjualbelikan. Suatu perkiraan yang dilakukan secara berulang-ulang akan menimbulkan kepastian.

Oleh karenanya apabila kita hubungkan antara penjelasan yang telah dipaparkan oleh Imam Nawawi di atas dan praktik yang terjadi di desa Gema kecamatan Kampar Kiri Hulu sesungguhnya sudah sejalan meskipun secara dzat-nya, obyek jual beli tersebut diketahui oleh kedua belah pihak dan tidak diketahui secara sifat dan ukuran.

\section{Jual Beli Tonak Lopeh menurut Prinsip-Prinsip Akad dalam Islam}

Mufassir mengatakan bahwa yang dimaksud akad dalam Islam adalah meliputi seluruh perkara yang diharuskan oleh Allah SWT kepada hambahambaNya dan yang Dia ikatkan kepada mereka berbagai beban dan hukumhukum agama (Sabatin, 2009: 36). Sehingga perkara apa saja yang diakadkan wajib dipenuhi. Termasuk akad jual beli hewan tonak lopeh di desa Gema. Masyarakat desa Gema yang mayoritas muslim tentu akan memperhitungkan aspek ukhrawi ketika akan melakukan kecurangan dalam proses jual beli tersebut. Akad yang dilakukan berdasarkan hukum Islam memiliki konsekuensi duniawi dan ukhrawi (Za'tari, 2006: 21). Lebih lanjut Qordlowi mengatakan bahwa apapun yang mengikat secara agama mengikat pula secara hukum (Faisal, 2014: 386). 
Prinsip-prinsip akad dalam Islam adalah sebagai berikut: Pertama, Hurriyah at Ta'uqud atau kebebasan berkontrak. Kontrak sendiri disebut juga dengan akad atau perjanjian, yaitu bertemunya ijab yang diberikan oleh salah satu pihak dengan kabul yang diberikan oleh pihak lainnya secara sah menurut hukum syar'i dan menimbulkan akibat pada subjek dan objeknya (Yulianti, 2008: 93). Prinsip hurriyah at Ta'uqud merupakan wujud dari kebebasan berkontrak. Masing-masing pihak yang akan mencapai tujuan akad mempunyai kebebasan untuk mengadakan penyusunan perjanjian atau freedom of making contract. Asas kebebasan berkontrak menempatkan para pihak yang berkontrak dalam posisi yang setara secara proposional. Asas ini tidak menempatkan para pihak untuk saling berhadapan, menjatuhkan dan mematikan sebagai lawan kontrak, justru sebaliknya asas ini menempatkan para pihak sebagai partner mitra kontrak pertukaran kepentingan mereka (Hernoko, 2013: 112). Demikian pula prinsip Hurriyah at Ta'uqud. Jika dikaitkan dengan jual beli tonak lopeh, prinsip ini telah dipenuhi sebagaimana hasil wawancara dengan bapak Idris sebagai pihak pembeli hewan tonak lopeh: "Saya beli kerbau itu ada yang beli sekaki (satu perempat bagian), sapagho (setengah bagian), setelah itu ya samasama memeliharanya. Nah itu tergantung bagian masing-masing. Biasanya yang sering saya beli itu kerbau, sapi juga pernah tapi jarang”. Dari kalimat saya beli kerbau sekaki (seperempat) atau sapagho (separuh) menunjukkan adanya prinsip hurriyyah atau kebebasan dalam berakad. Dalam hal ini bebas untuk menentukan isi akad. Pembeli atau penjual juga bebas untuk menentukan dengan siapa mereka akan melakukan akad.

Kedua, al Musawah atau persamaan. Muamalah merupakan suatu ketentuan hukum yang mengatur hubungan akan sesama manusia untuk nanti dapat memenuhi suatu kebutuhan hidup. Dengan adanya perilaku saling membutuhkan, maka setiap manusia memiliki kesamaan hak untuk dapat mengadakan perikatan (Susamto, 2009: 43). Dikatakan demikian, karena pada prinsipnya manusia adalah sama. Sedangkan yang membedakan hanya ketakwaannya. Allah SWT berfirman: "Sesungguhnya orang yang paling mulia disisi Allah SWT diantara kamu ialah orang yang paling bertakwa" (QS. al Hujurat: 13). Dari prinsip ini pun praktik jual beli hewan tonak lopeh di desa Gema juga telah memenuhi. Hal ini dapat dilihat dari hasil wawancara yang mengatakan bahwa ketika pembeli ingin membeli hewan tonak lopeh, maka si pembeli mencari orang yang hendak menjual. Setelah itu dilakukan proses akad tanpa membedakan siapa penjual dan siapa pembeli. Tidak membedakan pangkat ataupun golongan dari penjual ataupun pembeli. Mereka hanya 
mempunyai persamaan yaitu sama-sama saling membutuhkan satu sama lain. Karena adat ini berlangsung terus-menerus, mereka mempunyai jalinan atau ikatan sosial dan budaya dalam konteks masyarakat adat yang sama.

Ketiga, At Tawazun atau keseimbangan. Secara faktual, masing-masing pihak yang akan mengadakan kontrak memiliki berbagai latar belakang yang berbeda, namun hukum Islam tetap menekankan perlunya berpegang kepada prinsip keseimbangan, karena prinsip keseimbangan dalam akad terkait dengan pembagian hak dan kewajiban. Hak penjual adalah menerima uang dan hak pembeli adalah diberikan barang (obyek atau ma'qud alaih). Sedangkan kewajiban pembeli adalah menyerahkan uang dan kewajiban penjual adalah menyerahkan barang. Dalam jual beli hewan tonak lopeh ini hak dan kewajiban sudah dianggap sama-sama diketahui baik oleh penjual dan pembeli termasuk kewajiban penjual untuk memelihara ma'qud alaih dan kewajiban berbagi ganti kerugian secara proporsional kepemilikan antara penjual dan pembeli apabila ma'qud alaih merusak kebun milik warga. Dengan demikian prinsip ini tercapai karena tidak ada pihak yang dirugikan.

Keempat, al Amanah atau kepercayaan. Amanah merupakan bentuk kepercayaan yang timbul karena adanya itikad baik dari masing-masing pihak untuk mengadakan akad. Dalam hukum perjanjian syariah, terdapat bentuk akad yang bersifat amanah. Maksud amanah disini dapat diartikan sebagai kepercayaan kepada pihak lain untuk kemudian menjalin kerja sama. Dasar hukumnya ialah dari firman Allah yang menyatakan bahwa: "Sesungguhnya Allah menyuruh kamu menyampaikan amanat kepada yang berhak menerima" (QS. an Nisa: 58). "Maka hendaklah yang dipercayai itu menunaikan amanatnya" (QS. al Baqarah: 283) "Wahai orang-orang yang beriman, Janganlah kamu mengkhianati Allah dan Rasul dan (juga) janganlah kamu mengkhianati amanat yang dipercayakan kepadamu, sedang kamu mengetahui" (QS. al Anfal: 27).

Kelima, al adalah atau keadilan. Pelaksanaan dari prinsip ini dalam suatu perjanjian atau akad menuntut para pihak untuk melakukan yang benar di dalam pengungkapan suatu kehendak dan keadaan, memenuhi semua kewajibannya. Perjanjian harus senantiasa mendatangkan keuntungan yang adil dan seimbang, serta tidak boleh mendatangkan kerugian bagi salah satu pihak. Untuk itu Allah SWT berfirman:

"Hai orang-orang yang yang beriman, hendaklah kamu jadi orang-orang yang selalu menegakkan kebenaran karena Allah, menjadi saksi dengan adil. Dan janganlah sekali-kali kebencianmu terhadap suatu kaum, membuat kamu cenderung untuk berlaku tidak adil. Berlaku adillah karena adil itu lebih dekat kepada takwa. Dan 
bertakwalah kepada Allah, sesungguhnya Allah Maha Mengetahui apa kamu kerjakan" (QS. al Maidah : 8).

Dalam praktek jual beli hewan tonak lopeh, hal ini tercermin dari tanggung jawab yang muncul ketika para pihak harus mengganti kerugian bilamana ternak mereka merusak kebun warga. Mereka harus mengganti jumlah kerugian yang diderita warga dengan jumlah sesuai dengan bagian masing-masing. Dalam hal ini berarti ada prinsip keadilan khususnya keadilan yang proporsional.

Keenam, al Ridha atau kerelaan. Prinsip ini menyatakan bahwa segala transaksi yang dilakukan harus atas dasar kerelaan antara setiap pihak, harus didasarkan pada kesepakatan bebas dari para pihak dan tidak boleh ada unsur paksaan, tekanan, penipuan, dan misstatemen. Dasar hukum adanya asas kerelaan dalam perbuatan perjanjian terdapat dalam QS. an Nisa: 29, yang artinya sebagai berikut:

"Hai orang-orang yang beriman, janganlah kamu saling memakan harta dari sesamamu dengan jalan yang bathil, kecuali dengan jalan perniagaan yang berlaku dengan suka sama suka di antara kamu. Dan janganlah kamu membunuh dirimu, sesungguhnya Allah adalah Maha Penyayang kepadamu".

Ketujuh, Ash-Shiddiq atau kejujuran. Kejujuran merupakan hal yang prinsip bagi manusia dalam segala aspek bidang kehidupan, termasuk di dalam penyusunan kontrak muamalah. Jika kejujuran tidak diamalkan dalam penyusunan kontrak, maka akan merusak keridhaannya (uyub al ridha). Di samping itu, ketidakjujuran di dalam penyusunan perjanjian akan berakibat perselisihan di antara para pihak. Allah berfirman: "Hai orang-orang yang beriman, bertakwalah kamu kepada Allah, dan berkatalah perkataan yang benar" (QS. al Ahzab: 70). Dalam haditsnya Rasulullah SAW bersabda: "Jika kamu menjual barang dagangan, maka katakanlah tidak ada penipuan" (HR. Bukhari).

Kedelapan, itikad baik. Untuk dapat mengadakan kontrak haruslah dilaksanakan berdasarkan itikad baik. Di dalam pandangan Islam, niat merupakan prinsip mendasar terkait dengan unsur kepercayaan sebelum dapat melakukan suatu amal perbuatan (Usanti, 2013: 49-50). Dalil syariah yang menjadi dasar hukum berlakunya asas itikad baik adalah hadits Nabi yang menyatakan: "Sesungguhnya amal perbuatan tergantung pada niat, dan sesungguhnya tiap-tiap orang tergantung dari apa yang diniatkannya" (HR. Bukhari).

Prinsip-prinsip dalam akad jual beli tersebut di atas pada dasarnya harus ada sebelum dilakukannya jual beli. Beberapa prinsip sesungguhnya 
terangkum di dalam rukun dan syarat jual beli; misal dalam prinsip hurriyyah, prinsip kebebasan ini dalam rukun akad yaitu adanya aqid atau pihak yang berakad. Dalam hal ini para pihak dapat menentukan sendiri dengan siapa ia hendak melakukan akad. Demikian pula prinsip-prinsip yang lain. Prinsip kerelaan dan kejujuran terangkum pula dalam rukun dan syarat akad dalam hal adanya shighat. Shighat dalam akad jual beli adalah cerminan sah atau tidaknya akad jual beli yang dilakukan. Shighat haruslah jelas dan transparan, tidak boleh ada sesuatu yang disembuyikan apalagi menyesatkan pihak yang lain. Disebut jelas sebagaimana dikatakan oleh pembeli ketika hendak membeli hewan tonak lopeh, bahwa ia hendak membeli separuh, seperempat, seperdelapan atau seperenambelas dengan mabi' sapi atau kerbau. Dengan demikian prinsip kerelaan dan kejujuran dapat terpenuhi jika rukun dan syarat shighat telah terpenuhi.

\section{Praktik Jual Beli Hewan Tonak lopeh dalam Kajian Urf}

Jual beli tonak lopeh telah menjadi kebiasaan yang turun-menurun, sebagaimana disampaikan oleh bapak Syahril sebagai pihak yang pernah membeli hewan tonak lopeh sebagai berikut :

"jual boli kobau model iko go la ada sajak zaman dulu. Kalau la punya bagian awak misalnyo mamboli kobau sakaki, nah samo-samo awak paliagho. Kok sakiknya soto molo. Kok masuknyo ka dalam polka ughang samo bagi rato untung ugi. Atau baanaknyo awak bagi lo. Manfaatnya itu kombang biaknyo banak binaknya. Kalo tadosak awak bisa dijual dan sonang mamboli karono kalau sapagho kan dak boghek do mancindo siku o mahal kalo siku kobau".

Dari penjelasan di atas dapat difahami bahwa jual beli ternak lepas seperti ini sudah menjadi kebiasaan atau adat masyarakat desa Gema sejak zaman dahulu. Jumlah kepemilikan menentukan pula besar tanggung jawab ketika hewan tersebut sakit atau masuk ke kebun warga. Pemilik harus ikut menggantinya dan dibagi rata sesuai kepemilikan bagian. Karena sudah menjadi adat atau kebiasaan, maka sudah bisa diperkirakan bahwa permasalahan hukum yang timbul dari jual beli tonak lopeh ini sudah mendapat penyelesaiannya, kecuali timbul masalah-masalah baru yang perlu dicarikan kembali solusinya.

Dalam hukum konvensional, adat atau kebiasaan dapat menjadi hukum adat atau hukum kebiasaan dengan persyaratan:

Syarat materiil: adanya kebiasaan atau tingkah laku yang tetap atau diulang yaitu suatu rangkaian perbuatan yang sama, yang berlangsung untuk beberapa waktu lamanya. Harus dapat ditunjukkan adanya perbuatan yang berlangsung 
lama: harus ada apa yang dinamakan longa et inveterata consuetudo

Syarat intelektual: kebiasaan itu harus menimbulkan opinio necessitatis (keyakinan umum) bahwa perbuatan itu merupakan kewajiban hukum. Keyakinan ini tidak hanya merupakan keyakinan bahwa selalu ajeg berlaku demikian, tetapi keyakinan bahwa memang seharusnya demikian. Keyakinan ini disebut opinio nescessitatis (pendapat bahwa demikianlah seharusnya). Kebiasaan itu harus dilakukan karena keyakinan, bahwa hal itu patut secara objektif dilakukan, bahwa dengan melakukan itu berkeyakinan melakukan suatu kewajiban hukum.

Adanya akibat hukum apabila kebiasaan itu dilanggar (Ishaq, 2016: 124). Hukum adat atau hukum kebiasaan, diakui keberadaanya dan menjadi salah satu sumber hukum di Indonesia. Pasal 1339 KUHP perdata berbunyi : "perjanjian tidak hanya mengikat untuk hal-hal yang dengan tegas dinyatakan di dalamnya, tetapi juga untuk segala sesuatu yang menurut sifat perjanjiannya diharuskan oleh kepatutan, kebiasaan atau undang-undang”. Dalam praktik jual beli tonak lopeh ini, tidak diperjanjikan secara nyata bahwa apabila hewan ternak itu merusak kebun warga, maka ganti kerugian akan ditanggung bersama secara proporsional berdasarkan besarnya kepemilikan. Hal ini sebagaimana dinyatakan oleh Bapak Syahril di atas. Dengan demikian ini sesuai dengan pasal 1347 KUHP perdata yang mengatakan: "hal-hal yang menurut kebiasaan selamanya diperjanjikan, dianggap secara diam-diam dimasukkan dalam perjanjian meskipun tidak secara nyata".

Dasar hukum lain yang menunjukkan diakuinya hukum adat adalah pasal 5 ayat (1) dan (2) UU No. 48 Tahun 2009 tentang Kekuasaan Kehakiman, bahwa: "hakim dan hakim konstitusi wajib menggali, mengikuti, dan memahami nilai-nilai hukum dan rasa keadilan yang hidup dalam masyarakat" (Aristya, 2012: 28).

Pasal 1 ayat (3) Undang-Undang Dasar Negara Republik Indonesia Tahun 1945 menyatakan bahwa negara Indonesia adalah negara hukum. Negara ini berdiri di atas sebuah grundnorm (norma dasar). Grund norm ini merupakan sebuah konsep yang dikembangkan oleh Hans Kelsen dalam teori Hukum Murni (the Pure Theory of Law). Norma dasar ini merupakan norma tertinggi dalam suatu Negara dan harus ditaati dan menjiwai seluruh peraturan di bawahnya berupa konstitusi yang mengamanatkan pengakuan dan penghormatan atas keberadaan hukum adat. Pasal 18B ayat (2) UndangUndang Dasar Negara Republik Indonesia Tahun 1945 menyatakan : "Negara mengakui dan menghormati kesatuan-kesatuan masyarakat hukum adat beserta 
hak-hak tradisionalnya sepanjang masih hidup dan sesuai dengan perkembangan masyarakat dan prinsip Negara Kesatuan Republik Indonesia, yang diatur dalam undang-undang". Hukum adat terdiri atas asas-asas dan norma yang terbentuk berdasarkan kebiasaan, tradisi dan kepercayaan anggota masyarakat yang hidup di suatu wilayah tertentu, yang mengakar sebagai pedoman hidup dan tingkah laku dalam komunitasnya.

Kewajiban normatif hakim berdasarkan pasal 5 ayat (1) Undang-Undang Kekuasaan Kehakiman adalah menggali "the living customary law" atau hukum adat yang tumbuh dan berkembang dalam masyarakat (Syahbandir, 2010: 3). Hal ini tercipta dari kearifan lokal. Kearifan lokal merupakan bagian dari budaya suatu masyarakat yang tidak dapat dipisahkan dari bahasa masyarakat itu sendiri. Kearifan lokal biasanya diwariskan secara turun-temurun dari satu generasi ke generasi melalui cerita dari mulut ke mulut. Kearifan lokal ada di dalam cerita rakyat, peribahasa, lagu, dan permainan rakyat. Kearifan lokal sebagai suatu pengetahuan yang ditemukan oleh masyarakat lokal tertentu melalui kumpulan pengalaman dalam mencoba dan diintegrasikan dengan pemahaman terhadap budaya dan keadaan alam suatu tempat (Kearifan lokal, tt).

Dalam hukum Islam, kata adat diartikan dengan urf, meskipun ada beberapa pendapat yang membedakannya. Kata urf berasal dari kata arafa ya'rifu (عرف يعرف) sering diartikan dengan "al ma'ruf" (المعرف) dengan arti : "sesuatu yang dikenal". Kalau dikatakan فلالن اولى فلان عرفا (Si fulan lebih dari yang lain dari segi urf-nya) maksudnya bahwa si Fulan lebih dikenal dibandingkan dengan yang lain. Pengertian "dikenal" ini lebih dekat kepada pengertian "diakui oleh orang lain”. Kata urf juga terdapat dalam al Quran dengan arti ma'ruf yang artinya kebajikan (berbuat baik):

Artinya : "maafkanlah dia dan suruhlah berbuat ma'ruf" (QS. al A'raf : 199). Diantara ahli bahasa Arab ada yang menyamakan kata adat dan urf tersebut, kedua kata itu mutaradif (sinonim). Seandainya kedua kata itu dirangkaikan dalam suatu kalimat, seperti: hukum itu didasarkan kepada adat dan urf, tidaklah berarti kata adat dan urf itu berbeda maksudnya meskipun digunakan kata sambung "dan" yang biasa dipakai untuk yang membedakan dua kata. Karena kedua kata itu memiliki arti yang sama, maka dalam contoh tersebut, kata urf adalah sebagai penguat terhadap kata adat.

Abd. Wahab Khallaf menyatakan bahwa urf adalah: "sesuatu yang dikenal manusia dan dijalankan secara biasa, baik berupa perkataan ataupun perbuatan" (Harisudin, 2016: 68). Tidak jauh berbeda, Wahbah Zuhaili mendefinisikan 
urf sebagai sebagai: "Sesuatu yang dibiasakan oleh manusia, dan dijalaninya dari tiap perbuatan yang telah popular di antara mereka, atau juga lafadz yang dikenal dengan sebuah arti khusus yang tidak dicakup bahasa serta hanya (cepat) memungkinkan makna ketika didengarkan".

Ahmad Fahmi Abu Sunah menyebut urf: "Sesuatu yang terpatri dalam jiwa karena dipandang rasional dan penerimaan watak yang sehat atasnya”. Abu Sunah menegaskan betapa tidak semua kebiasaan dianggap sebagai urf. Di samping karena berulangkali telah dilakukan dan menjadi kebiasaan sebagai bentuk kesepakatan para pelakunya, maka urf harus bisa diterima oleh akal sehat atau rasional. Persyaratan ini jelas meminggirkan urf negatif atau yang juga disebut dengan urf yang fasid.

Sesungguhnya, prasyarat minimal keberlakuan urf hanya dua; ketetapan (al istiqrar) dan kontinuitas (al istimrar). Istiqrar menunjukkan bahwa urf harus merupakan sesuatu yang mendapat kesepakatan antar para pelaku-pelakunya. Di pihak lain, adanya al istimrar dimaksudkan agar urf dapat dijadikan pedoman hukum yang memadai dan permanen serta tidak berubah-ubah. Karena, bagaimana jadinya, jika hukum Islam yang semestinya didasarkan pada prinsip stabilitas hukum (istiqamat al hukm), tiba-tiba harus berubah-ubah dan berwatak temporer dalam tempo waktu yang sangat cepat.

Oleh karena itu, Islam hadir tidak sedang memusnahkan urf yang tumbuh berkembang di masyarakat. Justru, Islam hadir dengan keadaan menyeleksi urf-urf yang ada. Jika tidak bertentangan dengan Islam, urf terus berjalan. Sebaliknya, jika bertentangan, Islam memusnahkan atau memodifikasinya agar sesuai dengan nilai-nilai ajaran Islam. Definisi Abu Sunah di atas harus diarahkan pada urf yang ideal dan seharusnya, bukan urf yang realistis dan senyatanya yang terdapat dalam masyarakat kita.

Secara historis, akomodasi urf dalam Islam adalah sebuah keniscayaan. Bukti menujukkan beberapa urf pada masa sebelum Muhammad SAW diadopsi dalam agama Islam. Muhammad acapkali menetapkan adat-adat Arab yang sudah berkembang secara turun-temurun dari nenek moyang mereka. Penetapan ini dalam hadits disebut dengan sunnah taqririyah. Ini artinya senyampang tidak bertentangan dengan syariat Islam, Nabi SAW lebih mengakomodasi urf yang ada di Arab. Nabi SAW sadar bahwa urf ini tidak seketika dapat dihapuskan, namun justru malah dijadikan penguat ajaran Islam dengan melegalkannya (Harisudin, 2016: 69). 
Dengan demikian, semakin jelas bahwa urf bukan metode hukum Islam yang mandiri, melainkan harus berdasarkan pertimbangan lain. Ketika urf ditetapkan sebagai urf shahih, maka harus dijumpai adanya dasar lain yang mengatakan demikian. Misalnya mashlahah atau istihsan yang mendasari adanya urf tersebut. Oleh karena itu, urf yang berlaku di beberapa tempat seperti melangkahi kakak untuk menikah dengan membayar sejumlah uang tertentu, merarik (nikah culik), petik laut dan sebagainya harus dikorelasikan dengan kemaslahatan atau kemadlaratan yang diakibatkan oleh urf tersebut. Sebaliknya, ketika menetapkan maslahah, maka tidak bisa lepas dari ruang dan waktu. Maslahah baru terlihat ketika diletakkan dalam konteks tempat dan waktu tertentu. Karena itu, sebuah maslahah dalam ruang dan waktu tertentu belum tentu menjadi maslahah pada ruang dan waktu yang lain. Di sinilah, urf yang berbeda-beda dapat menetapkan hukum yang berbeda-beda pula, sesuai dengan pertimbangan maslahah yang melatarinya (Harisudin, 2016).

Terdapat beberapa macam urf. Macam-macam urf ini dapat dilihat dari beberapa segi:

Ditinjau dari segi materi yang biasa dilakukan. Dari segi ini urf itu ada dua macam:

1. Urf qauli (عرف قولي), yaitu kebiasaan yang berlaku dalam penggunaaan kata-kata ucapan,

2. Urf fi'li (عرف فعلي) yaitu kebiasaan yang berlaku dalam perbuatan.

Ditinjau dari segi ruang lingkup penggunaanya, urf terbagi kepada :

1. Urf umum (عرف عام), yaitu kebiasaan yang telah umum berlaku dimanamana;

2. Adat atau urf khusus (عرف خاص), yaitu kebiasaan yang dilakukan oleh suatu kelompok orang ditempat tertentu atau pada waktu tertentu; tidak berlaku di sembarang tempat atau sembarang waktu.

Dari segi penilaian baik dan buruk, adat atau urf terbagi kepada:

1. Urf Shahih (عرف صحيح), yaitu urf yang berulang-ulang dilakukan, diterima oleh orang banyak, tidak bertentangan dengan hukum syara', sopan santun, dan budaya yang luhur; di lain perkataan, urf sahih merupakan kebiasaan masyarakat dalam bentuk perkataan atau tindakan yang diakui oleh dalil-dalil normatif hukum Islam. Urf shahih mempunyai kedudukan hukum yang kuat, bahkan dapat dikukuhkan sebagai bagian integral dari penetapan hukum Islam sebagaimana kaidah: al adah al muhakkahmah (tradisi dapat dikukuhkan menjadi ketentuan hukum Islam) (Sirajuddin, 
2015: 18).

2. Urf fasid (عرف فاسد), yaitu adat atau urf yang berlaku di suatu tempat meskipun merata pelaksanaannya, namun bertentangan dengan hukum syara', undang-undang negara, dan sopan santun. Dengan kata lain urf fasid yaitu kebiasaan dalam bentuk perkataan dan tindakan yang dikenal dan diamalkan masyarakat, tetapi hal itu bertentangan dengan norma hukum syara' (Sirajuddin, 2015: 18).

Jual beli tonak lopeh termasuk ke dalam urf shohih atau urf maslahah. Karena praktek jual beli tersebut dilakukan atau terjadi akibat kristalisasi kebutuhan masyarakat yang notabene bermata pencaharian peternak atau bertani dengan tingkat ekonomi menengah ke bawah. Sebagaimana dari hasil wawancara dikatakan bahwa mereka menjual hewan ternak karena membutuhkan uang. Sedangkan pembeli membeli sebagian saja hewan ternak karena tidak memiliki uang untuk membeli satu ekor. Hal ini sejalan dengan definisi menurut al Thufi: dilihat dari segi lafadznya, kata mashlahah mengandung makna "keberadaan sesuatu dalam keadaannya yang sempurna, ditinjau dari segi bahwa fungsi sesuatu itu sesuai dengan peruntukkannya”. Contoh sesuai dengan fungsinya pena cocok untuk menulis dan pedang sesuai dengan fungsinya cocok untuk memotong (menebas). Sedangkan secara terminologi, mashlahah menurut al Thufi dapat dilihat dari dua segi, yaitu urf dan syara'. Menurut urf, yang dimaksud mashlahah adalah "sebab yang membawa dan melahirkan keuntungan”, misalnya perdagangan merupakan sebab yang akan membawa dan melahirkan keuntungan. Pengertian mashlahah secara urf di atas sejalan dengan pengertian yang terdapat dalam kamus-kamus bahasa Arab. Dapat disimpulkan, secara kebahasaan dan 'urf, mashlahah berarti manfaat, guna, kebaikan, sedangkan lawannya adalah mafsadah (kerusakan) (Qusthoniah, 2013: 40-41).

\section{Simpulan}

Imam Nawawi mensyaratkan bahwa obyek jual beli tidak boleh separuhnya atau sebagiannya, kecuali tidak berkurang nilai dan manfaat dari barang tersebut. Dalam praktik jual beli hewan tonak lopeh, meskipun objek jual beli hanya sebagiannya, tetapi nilai dan manfaatnya tidak berkurang. Barang yang menjadi objek jual beli meskipun belum diketahui secara jelas dari aspek ukuran dan sifatnya, yakni dalam hal ini kerbau atau sapi yang demikian, tidak diketahui bagian yang dimiliki oleh si penjual dan si pembeli. Namun hal ini tidak berpengaruh ketika dimaksudkan tidak untuk dimakan, 
melainkan untuk manfaat yang lain seperti membajak sawah, dijual kembali untuk memperoleh keuntungan atau dikembangbiakkan.

Praktik jual beli hewan tonak lopeh di desa Gema merupakan suatu adat atau kebiasaan masyarakat yang membawa manfaat bagi masyarakat tersebut. Msyarakat yang tidak mampu membeli satu bagian dari obyek jual beli dapat membeli sebagiannya saja, tidak perlu membuat kandang dan merawat sendiri bagi pembeli, dan tidak membawa madlarat. Dengan demikian adat atau kebiasaan ini secara urf diperbolehkan dan merupakan urf shohih yaitu urf yang berulang-ulang dilakukan, diterima oleh orang banyak, tidak bertentangan dengan hukum syara', sopan santun, dan budaya yang luhur.

\section{Daftar Pustaka}

Ardhinata. 2015. Keridhaan (Antaradhin) Dalam Jual Beli Online (Studi Kasus UD. Kuntajaya Kabupaten Gresik). JESTT. Vol. 2 Nomor 1: 52.

Aristya \& Sulastriyono. 2012. Penerapan Norma Dan Asas-Asas Hukum Adat Dalam Praktik Peradilan Perdata. Mimbar Hukum. Vol. 24, No. 1: 28.

Azwar, Saifuddin. 2013. Metode Penelitian. Yogyakarta: Pustaka Pelajar.

Faisal. 2014. Metode Anuitas dan Proporsional Murabahah sebagai Bentuk Transparansi dan Publikasi Laporan Bank. Mimbar Hukum. Vol. 26, No. 3: 386 .

Harisudin. 2016. Urf Sebagai Sumber Hukum Islam (Fiqh) Nusantara. Al Fikr. Vol. 20, No. 1: 68-69.

Hernoko, Agus Yudha. 2013. Hukum Perjanjian: Azas Proporsionalitas dalam Kontrak Komersial. Jakarta: Kencana.

Kearifan lokal, tt. Http://id.wikipedia.org/wiki. diakses pada tanggal 21 Juli 2017.

Ishaq. 2016. Dasar-Dasar Ilmu Hukum. Jakarta: Sinar Grafika.

Jahar, Asep Saepudin., dkk. 2013. Hukum Keluarga, Pidana $\mathcal{E}$ Bisnis. Jakarta: Kencana.

Mahfudh, Sahal. 2014. Nuansa Fiqh Sosial, cet-IV. Yogyakarta: Lkis.

Nawawi. 2005. Minhaj Al Thalibin Wa Umdatul Muftin. Lebanon-beirut: Darul Minhaj.

Qusthoniah. 2013. Al Mashlahah dalam Pandangan Najmuddin Al Thufi. Jurnal Syari'ah. Vol. II, No. II: 40-41. 
Sabatin, Yusuf As. 2009. Bisnis Islami dan Kritik atas bisnis kapitalis. Bogor: Al Ahzar Press.

Setiady. 2014. Pembiayaan Murabahah Dalam Perspektif Fikih Islam, Hukum Positif dan Hukum Syariah. Fiat Justisia. Vol.8, No. 3: 520.

Sirajuddin. 2015. Eksistensi Urf Sebagai Sumber Pelembagaan Hukum Nasional. Madania. Vol. 19, No. 1-3.

Sunggono, Bambang. 2003. Metodologi Penelitian Hukum. Jakarta: PT Raja Grafindo Persada.

Susamto, Burhanuddin. 2009. Hukum Kontrak Syariah. Yogjakarta: BPFE.

Syafi'i, Rachmat. 2001. Figh Mua'amalah. Bandung: Pustaka Setia.

Syahbandir. 2010. Kedudukan Hukum Adat Dalam Sistem Hukum (The Structure of Customary Law In Indonesia's Legal System). Kanun. No. 50 Edisi April: 3.

Usanti. 2013. Akad Baku Pada Pembiayaan Murabahah Di Bank Syariah. Perspektif. Vol. XVIII, No. 1: hal 49-50.

Yulianti. 2008. Asas-Asas Perjanjian (Akad) dalam Hukum Kontrak Syari'ah. La Riba. Vol. II, No.1-93.

Za'tari, Alauddin. 2006. Al Masharif Al Islamiyah Wa Madza Yajibu An Yu'rafu 'Anha. Damaskus: Dar Ghar Hira. 